\title{
Fusarium verticillioides Strains Isolated from Corn Feed: Characterization by Fumonisin Production and RAPD Fingerprinting
}

\author{
Elisabete Yurie Sataque Ono ${ }^{1 *}$, Maria Helena Pelegrinelli Fungaro ${ }^{2}$, Silvia Helena Sofia ${ }^{2}$, \\ Tatiana de Ávila Miguel ${ }^{1}$, Yoshitsugu Sugiura ${ }^{3}$ and Elisa Yoko Hirooka ${ }^{4}$ \\ ${ }^{1}$ Universidade Estadual de Londrina; Departamento de Bioquímica e Biotecnologia; C. P.: 6001; 86051-990; \\ Londrina - PR - Brasil. ${ }^{2}$ Departamento de Biologia Geral; C. P.: 6001; 86051-990; Londrina - PR - Brasil. ${ }^{3}$ Kobe \\ Institute of Health; Department of Food Chemistry; 4-6 Minatojima-nakamachi; Chuo- ku; Kobe 650-0046; Japan. \\ ${ }^{4}$ Universidade Estadual de Londrina; Departamento de Ciência e Tecnologia de Alimentos; C. P.: 6001; 86051- \\ 990; Londrina - PR - Brasil
}

\begin{abstract}
In this study a total of 16 Fusarium verticillioides strains isolated from corn feed samples were characterized by fumonisin $(F B)$ production and random amplified polymorphic DNA (RAPD). All the strains produced $F B_{1}$ and $F B_{2}$ with levels ranging from 2.41 to $3996.36 \mu \mathrm{g} / \mathrm{g}$, and from 1.18 to $1209.91 \mu \mathrm{g} / \mathrm{g}$, respectively. From the $16 \mathrm{~F}$. verticillioides strains, four were identified as low (3.59 to $1289.84 \mu \mathrm{g} / \mathrm{g})$, eight as intermediate (>1289.84 to $3772.44 \mu \mathrm{g} / \mathrm{g}$ ) and four strains as high (>3772.44 $\mu \mathrm{g} / \mathrm{g})$ fumonisin producers. From the total of 105 loci amplified, $60(57.14 \%)$ were polymorphic. RAPD analysis showed very similar patterns among low, moderate and high fumonisin-producing strains. Although RAPD markers were capable of discriminating the different $F$. verticillioides strains, there was no clear association between these makers and fumonisin production.
\end{abstract}

Key words: Fumonisin, Fusarium verticillioides, genetic variability, RAPD

\section{INTRODUCTION}

Fusarium verticillioides Sacc. Nirenberg $(=F$. moniliforme Sheldon) is the prevalent seed-borne fungus in corn (Zea mays L.) with wide geographic distribution, but predominance in humid tropical and subtropical regions (Marasas et al., 1984). Fumonisins, the main toxic metabolites produced by this fungus, have been involved in animal intoxications (Sydenham et al., 1992) and their possible role as a cancer promoting agent (Ueno, 2000) included them in the group of extensively investigated mycotoxins. The severe economic losses in corn and other cereal crops worldwide, in addition to the potential occurrence of fumonisins and other mycotoxins in consequence of $F$. verticillioides infection are a matter of concern in current mycotoxicology. Although twenty-eight fumonisin analogues have been characterized to date, only $\mathrm{FB}_{1}$ and $\mathrm{FB}_{2}$ occur as natural contaminants at significant levels in corn and corn-based products (Gelderblom et al., 1988; Rheeder et al., 2002). Fusarium species are currently identified coupling

*Author for correspondence: eysono@uel.br 
microscopic / colony morphological characters (Nelson et al., 1983). The intraspecific characterization has been carried out by pathogenicity tests on a range of hosts, determination of vegetative compatibility group by pairing experiments, or evaluation of the mycotoxin production profile (Jiménez et al., 2000; Nicholson et al., 2003).

In the last two decades, advances in the development of numerous molecular techniques, which are able to detect an unlimited number of polymorphic loci in individual genotypes and to assess the genetic variation in populations, have allowed different genetic approaches in microorganisms (Edwards et al., 2002; Pamphile and Azevedo, 2002). According to Mitter et al. (2001), the study of Fusarium species has been greatly improved by the adoption of several molecular techniques, including specific diagnostic PCR (Polymerase Chain Reaction) primers, PCR-RFLP (Polymerase Chain Reaction - Restriction Fragment Length Polymorphism), AFLP (Amplified fragment length polymorphism), RAPD (Random Amplified Polymorphic DNA), among others. The random amplified polymorphic DNA (deoxyribonucleic acid) or RAPD technique is an alternative strategy for generating a polymorphic class of molecular markers (Williams et al., 1990), without any prior knowledge of DNA sequences in an organism. In Fusarium sp., RAPD has been applied in different approaches, such as to investigate the association between the genetic variability of the isolates and the locality of isolation and/or host plant populations (Kini et al. 2002; Pamphile and Azevedo, 2002), to elucidate the taxonomic status and relationships among Fusarium isolates, races and species (Miedaner et al., 2001), to investigate pathogenicity variation (Nelson et al., 1997; Carter et al., 2002; Cramer et al., 2003). In addition, RAPD assay has been used to study the relationship between mycotoxin production in different fungal species and the RAPD profiles; however no conclusive data have been found to date (Jiménez et al., 2000; TranDinh et al., 1999).

The aim of this study was to characterize 16 $F$. verticillioides strains isolated from corn feed samples according to their capability of fumonisin production under laboratory conditions and RAPD fingerprinting profiles. In addition, the possible relationship between RAPD genotypes and fumonisin production was investigated.

\section{MATERIALS AND METHODS}

\section{Fusarium verticillioides Strains}

F. verticillioides strains $(97 \mathrm{~J}, 97 \mathrm{~K}, 97 \mathrm{~L}, 103 \mathrm{BR}$, $103 \mathrm{G}, 103 \mathrm{~F}, 103 \mathrm{H}, 104 \mathrm{Ga}, 113 \mathrm{~B}, 113 \mathrm{~F}, 118 \mathrm{~F}$, 119B, 119BR, 119Fa, 162A, 164G), isolated from corn feed samples (Table 1) were morphologically identified at Science University of Tokyo, Japan. Strains with equal numbers were isolated from the same feed sample. Three culture media were used for Fusarium species isolation from the feed samples, i.e., peptone pentachloronitrobenzene agar (PPA, Nash and Snyder, 1962), dichloran chloramphenicol peptone agar (DCPA, Andrews and Pitt, 1986) and PCNB 2-amino butane medium (PAB, Jeffries et al., 1984). A $0.5 \mathrm{~mL}$ portion of feed sample suspension diluted in distilled water $\left(10^{-1}\right.$ to $\left.10^{-4}\right)$ was plated onto the agar surface in duplicate, and colonies from each plate were transferred to potato dextrose agar (PDA) slant. Then Fusarium sp.-like colonies were single-spored, inoculated into carnation leaf agar (CLA) medium (Fisher et al., 1982) and identified according to Nelson et al. (1983).

Table 1 - Source of Fusarium verticillioides strains.

\begin{tabular}{cccc}
\hline Feed sample & Feed composition & Source & F. verticillioides strains \\
\hline 97 & corn ear & Rolândia (PR) & $97 \mathrm{~J}, 97 \mathrm{~K}, 97 \mathrm{~L}$ \\
103 & corn residue & Guatambu (MS) & $103 \mathrm{~F}, 103 \mathrm{G}, 103 \mathrm{H}, 103 \mathrm{BR}$ \\
104 & corn residue & Guatambu (MS) & $104 \mathrm{Ga}$ \\
113 & corn residue & Mirasselva (PR) & $113 \mathrm{~B}, 113 \mathrm{~F}$ \\
118 & corn & Maringá (PR) & $118 \mathrm{~F}$ \\
119 & mixed feed & Maringá (PR) & $119 \mathrm{~B}, 119 \mathrm{Fa}, 119 \mathrm{BR}$ \\
162 & corn & Marília (SP) & $162 \mathrm{~A}$ \\
164 & mixed feed & Marília (SP) & $164 \mathrm{G}$ \\
\hline
\end{tabular}




\section{Fumonisin Production and Determination}

All the strains were grown on potato dextrose agar (PDA) slants at $28^{\circ} \mathrm{C}$ for 7 days. Each $F$. verticillioides strain $\left(10^{6}\right.$ conidia/mL $)$ was inoculated onto a Petri dish $(90$ x $20 \mathrm{~mm})$ containing $10 \mathrm{~g}$ of ground corn moistened with 10 $\mathrm{mL}$ distilled water, and autoclaved two times for $30 \mathrm{~min}$. The cultures were incubated at $25^{\circ} \mathrm{C}$ for 14 days. Fumonisins were determined by highperformance liquid chromatography (HPLC) according to Shephard et al. (1990) with some modification (Ueno et al., 1993). Culture samples were extracted with $60 \mathrm{~mL}$ methanol-water $(3: 1$, $\mathrm{v} / \mathrm{v})$. After $10 \mathrm{~min}$ incubation at room temperature, the suspension was shaken (150 rpm, $30 \mathrm{~min}$ ) and centrifuged ( $4500 \times \mathrm{x}, 10 \mathrm{~min}$ ).

One milliliter of the supernatant was applied onto a preconditioned Sep Pak accell plus QMA (quaternary methylammonium) cartridge (Waters Co., Ltd.). After washing the cartridge with methanol-water $(3: 1,6 \mathrm{~mL})$ followed by methanol $(3 \mathrm{~mL})$, the fumonisins were eluted with $10 \mathrm{~mL}$ methanol containing $0.5 \%$ acetic acid. The eluate was evaporated to dryness under a stream of nitrogen at $45^{\circ} \mathrm{C}$, and the residue was dissolved in methanol-water $(3: 1, \quad v / v, 800 \mu \mathrm{L})$. After derivatization with $200 \mu \mathrm{l} o$-phthaldialdehyde (OPA) reagent, HPLC injections were made within 1 min. Fumonisins were analyzed by a reversedphase, isocratic HPLC system (Shimadzu LC-10 AD pump and RF-10A XL fluorescence detector), using a Shim-pack CLC-ODS (M) column (4.6 x $250 \mathrm{~mm}$, Shimadzu). Excitation and emission wavelengths were 335 and $450 \mathrm{~nm}$, respectively. The eluent was $\mathrm{CH}_{3} \mathrm{OH}: 0.1 \mathrm{M} \mathrm{NaH}_{2} \mathrm{PO}_{4}$ (80:20, $\mathrm{v} / \mathrm{v}$ ) adjusted to $\mathrm{pH} 3.3$ with ortho-phosphoric acid at flow rate of $1 \mathrm{~mL} / \mathrm{min}$. The detection limits for $\mathrm{FB}_{1}$ and $\mathrm{FB}_{2}$ were 27.5 and $35.3 \mathrm{ng} / \mathrm{g}$, respectively.

\section{DNA Extraction and RAPD Analysis}

The nucleic acid extraction was carried out by culturing each strain in potato dextrose broth at $28^{\circ} \mathrm{C}$ for 6 days, and the mycelium was harvested by filtration. Genomic DNA was extracted from each strain according to Raeder and Broda (1985) with modification. Approximately $1 \mathrm{~g}$ of frozen mycelium was ground to a fine powder in liquid nitrogen and incubated with $800 \mu \mathrm{L}$ DNA extraction buffer (100 mM Tris-HCl, pH 8.0; $25 \mathrm{mM}$ EDTA - Ethylenediamine Tetraacetic Acid, 1\% SDS - Sodium Dodecyl Sulfate, 25 mM
$\mathrm{NaCl})$ at $65^{\circ} \mathrm{C}$ for $20 \mathrm{~min}$. The suspension was deproteinized by extracting once with an equal volume of phenol, followed by phenol: chloroform: isoamyl alcohol $(25: 24: 1, \mathrm{v} / \mathrm{v} / \mathrm{v})$ and then chloroform: isoamyl alcohol (24:1, v/v). DNA was precipitated by adding two volumes of ice-cold ethanol and $10 \% \quad 3 \quad \mathrm{M} \mathrm{NaCl}$. The precipitate was collected by centrifugation, washed with $70 \%$ ethanol, dried, and the pellet was resuspended in TE - Tris-EDTA buffer - (10 mM Tris, 1 mM EDTA pH 8.0). Fungal DNA sequences were amplified with primers purchased from Operon Technologies, Alameda, CA, USA. Primer screening was carried out using 13 primers for reproducible and scorable amplifications for the analysis of all the strains. The 10 primers selected were: OPA2, OPA7, OPA11, OPA18, OPE11, OPE16, OPC1, OPC5, OPC18 and OPX3. Purified and quantified DNA of each strain was subjected to PCR using 10-mer random primers. The PCR protocol was first optimized by varying the concentration of template DNA, Taq DNA polymerase and $\mathrm{MgCl}_{2}$ in order to obtain the maximum number of reproducible bands and further used in all analysis. In amplification reactions, the total reaction volume was $25 \mu \mathrm{L}$ and the conditions were: $0.25 \mu \mathrm{M}$ primer, $10 \mathrm{mM}$ Tris$\mathrm{HCl}(\mathrm{pH} 8.0), 50 \mathrm{mM} \mathrm{KCl}, 3.5 \mathrm{mM} \mathrm{MgCl}_{2}, 2 \mathrm{U}$ of native Taq DNA polymerase (Gibco-BRL), 0.25 $\mathrm{mM}$ of each dNTP (Pharmacia) and $25 \mathrm{ng}$ of DNA. Control reactions were run with all components except genomic DNA and none of the primers used yielded detectable amplified products in these reactions. DNA amplifications were carried out in a Techne Thermal Cycler as follows: $92^{\circ} \mathrm{C}$ for $3 \mathrm{~min}$ followed by 40 cycles of $92^{\circ} \mathrm{C}$ for $40 \mathrm{sec}, 40^{\circ} \mathrm{C}$ for $1.5 \mathrm{~min}, 72^{\circ} \mathrm{C}$ for $2 \mathrm{~min}$. The last round of amplification was followed by an additional extension at $72{ }^{\circ} \mathrm{C}$ for $5 \mathrm{~min}$. Amplification products were resolved by electrophoresis in $1.4 \%$ agarose gel, stained with ethidium bromide, photographed under UV light and scored visually for band presence and absence.

\section{Data Analysis}

Fumonisin $\left(\mathrm{FB}_{1}+\mathrm{FB}_{2}\right)$ production by $16 F$. verticillioides strains was analyzed by one-way ANOVA, followed by the Tukey multiple comparison test $(\mathrm{p}<0.05)$. Statistical analysis was performed by the 'Statistica' software version 6.0 (Stat Soft, Inc.).

The RAPD marker profiles were determined by direct comparison of the amplified DNA 
electrophoresis profiles, and each band was analyzed as a binary variable (band presence or absence). Only RAPD bands that were scored unequivocally were counted in the analysis. The RAPD data were entered into a binary matrix, and a pair-wise similarity matrix was constructed using the Jaccard similarity index (JS) (Sneath and Sokal, 1973). An UPGMA (unweighted pair group method using average-linkage) cluster based on JS values was generated using the NTSYS (Numerical Taxonomy System, Applied Biostatistics, Setauket, New York) computer application software (Rohlf, 2000).

\section{RESULTS AND DISCUSSION}

Fumonisin production in corn culture by $16 F$. verticillioides strains is shown in Table 2 . All the strains produced $\mathrm{FB}_{1}$ and $\mathrm{FB}_{2}$ with levels ranging from 2.41 to $3996.36 \mu \mathrm{g} / \mathrm{g}$ and from 1.18 to $1209.91 \mu \mathrm{g} / \mathrm{g}$, respectively (Table 2). The $\mathrm{FB}_{1}$ levels were similar to those found by Hinojo et al. (2004) but higher than those reported by Almeida et al. (2000). Hinojo et al. (2004) reported $\mathrm{FB}_{1}$ levels ranging from 56 to $4775 \mu \mathrm{g} / \mathrm{g}$ in cultures of $13 F$. verticillioides isolates from corn. Almeida et al. (2000) detected $\mathrm{FB}_{1}$ and/or $\mathrm{FB}_{2}$ production ranging from 20 to 2168 and from 10 to $380 \mu \mathrm{g} / \mathrm{g}$, respectively, in rice cultures of $40 \mathrm{~F}$. verticillioides strains isolated from corn. On the other hand, higher levels of $\mathrm{FB}_{1}$ and $\mathrm{FB}_{2}$ production have been reported by Acuña et al. (2005), who analyzed 34 $F$. verticillioides isolates from different feedstuffs and 33 of these isolates produced $\mathrm{FB}_{1}$ and $\mathrm{FB}_{2}$ at levels ranging from 5.6 to $25,846.4 \mu \mathrm{g} / \mathrm{g}$ and from 3.4 to $7507.5 \mu \mathrm{g} / \mathrm{g}$, respectively.

Table 2 - Fumonisin production by Fusarium verticillioides strains in corn culture material.

\begin{tabular}{|c|c|c|c|}
\hline F. verticillioides strains & $\mathrm{FB}_{1}(\mu \mathrm{g} / \mathrm{g})$ & $\mathrm{FB}_{2}(\mu \mathrm{g} / \mathrm{g})$ & $\mathrm{FB}_{1}+\mathrm{FB}_{2} *(\mu \mathrm{g} / \mathrm{g})$ \\
\hline $103 \mathrm{~F}$ & 3996.36 & 1122.90 & $5119.26^{\mathrm{a}} \pm 400.25$ \\
\hline $119 B$ & 3832.59 & 1209.91 & $5042.50^{\mathrm{ab}} \pm 81.32$ \\
\hline $97 \mathrm{~K}$ & 3098.88 & 952.80 & $4051.68^{\mathrm{ab}} \pm 433.43$ \\
\hline 119BR & 3256.08 & 792.18 & $4048.26^{\mathrm{ab}} \pm 164.36$ \\
\hline $119 \mathrm{Fa}$ & 2813.55 & 866.95 & $3680.50^{\mathrm{bc}} \pm 631.45$ \\
\hline $97 \mathrm{~L}$ & 2146.00 & 1084.00 & $3230.00^{\mathrm{C}} \pm 786.30$ \\
\hline $104 \mathrm{Ga}$ & 2390.22 & 754.02 & $3144.24^{\mathrm{cd}} \pm 244.72$ \\
\hline $162 \mathrm{~A}$ & 1162.08 & 640.98 & $1803.06^{\mathrm{de}} \pm 366.31$ \\
\hline $118 \mathrm{~F}$ & 1219.70 & 506.40 & $1726.10^{\mathrm{e}} \pm 68.57$ \\
\hline $97 \mathrm{~J}$ & 1230.99 & 397.16 & $1628.15^{\mathrm{e}} \pm 348.67$ \\
\hline $103 \mathrm{H}$ & 1025.72 & 585.78 & $1611.50^{\mathrm{e}} \pm 17.68$ \\
\hline 103BR & 1296.96 & 181.42 & $1478.38^{\mathrm{e}} \pm 61.99$ \\
\hline $113 \mathrm{~F}$ & 513.09 & 211.14 & $724.23^{\mathrm{ef}} \pm 48.75$ \\
\hline $103 \mathrm{G}$ & 168.60 & 56.14 & $224.74^{\mathrm{ef}} \pm 39.67$ \\
\hline $113 B$ & 109.39 & 106.21 & $215.60^{\mathrm{ef}} \pm 4.02$ \\
\hline $164 \mathrm{G}$ & 2.41 & 1.18 & $3.59^{\mathrm{f}} \pm 0.47$ \\
\hline
\end{tabular}

All the results are averages of replicate cultures and duplicate analysis

* Means followed by the same letter indicate no significant difference by the Tukey test $(\mathrm{p}<0.05)$.

The 16 strains were divided into three groups according to the total fumonisin $\left(\mathrm{FB}_{1}+\mathrm{FB}_{2}\right)$ production in culture material (Table 3), based on distribution in quartile (Statistica 5.0). The toxigenicity clustering resulted in Group 1 with four strains (3.59 to $1289.84 \mu \mathrm{g} / \mathrm{g}$ ), Group 2 with eight strains (>1289.84 to $3772.44 \mu \mathrm{g} / \mathrm{g}$ ) and Group 3 with four strains (>3772.44 $\mu \mathrm{g} / \mathrm{g}$ ), corresponding to $25 \%$ lower, $50 \%$ intermediate and $25 \%$ upper values, respectively. $F$. verticillioides strain $103 \mathrm{~F}$ produced the highest fumonisin level, while strain $164 \mathrm{G}$ the lowest (Table 3). All the strains belonging to the group of high fumonisin producers (Group 1) were statistically equivalent $(\mathrm{p}<0.05)$ in levels of fumonisin produced, when compared by the Tukey test (Table 2).

The ten primers used in the genetic analysis of 16 $F$. verticillioides strains generated a total of 105 reproducible RAPD bands, averaging 10.5 bands per primer. Among the 105 RAPD loci, 60 $(57.14 \%)$ were polymorphic. Extensive genetic 
variation among $F$. verticillioides strains have been reported elsewhere (Pamphile and Azevedo, 2002). In general, despite the genetic variation showed by $16 F$. verticillioides strains analyzed, there was considerable uniformity of banding patterns among these strains. A RAPD electrophoretic profile obtained with primer OPA2 is shown in Figure 1.

Table 3 - Clustering of $F$. verticillioides strains into groups according to fumonisin production in culture material based on distribution in quartile (Statistica 5.0).

\begin{tabular}{ccc}
\hline Group $($ range, $\boldsymbol{\mu g} / \mathbf{g})$ & $\boldsymbol{F}$. verticillioides strains & Total FB* $(\boldsymbol{\mu g} / \mathbf{g})$ \\
\hline 1 & $164 \mathrm{G}$ & 3.59 \\
$(3.59-1289.84)$ & $113 \mathrm{~B}$ & 215.60 \\
& $103 \mathrm{G}$ & 224.74 \\
& $113 \mathrm{~F}$ & 724.23 \\
& $103 \mathrm{BR}$ & 1478.38 \\
$(>1289.84-3772.44)$ & $103 \mathrm{H}$ & 1611.50 \\
& $97 \mathrm{~J}$ & 1628.15 \\
& $118 \mathrm{~F}$ & 1726.10 \\
& $162 \mathrm{~A}$ & 1803.06 \\
& $104 \mathrm{Ga}$ & 3144.24 \\
& $97 \mathrm{~L}$ & 3230.00 \\
3 & $119 \mathrm{Fa}$ & 3680.50 \\
& & \\
& $119 \mathrm{BR}$ & 4048.26 \\
& $97 \mathrm{~K}$ & 4051.68 \\
& $119 \mathrm{~B}$ & 5042.50 \\
\hline
\end{tabular}

*Total FB: $\mathrm{FB}_{1}+\mathrm{FB}_{2}$.

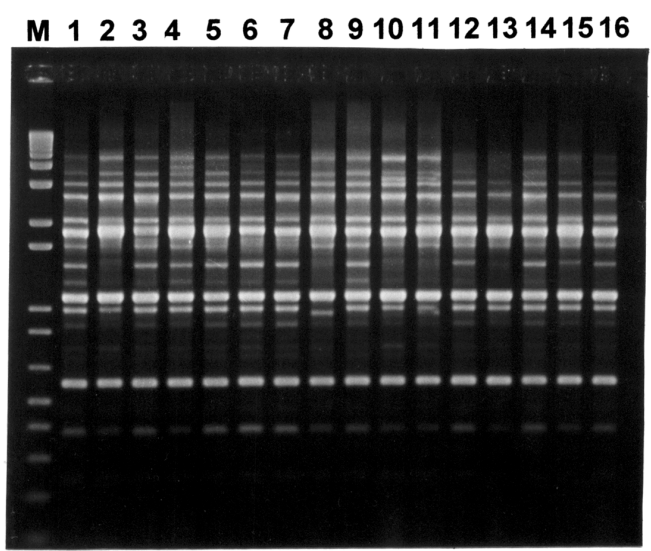

Figure 1 - Random amplification of polymorphic DNA from $16 F$. verticillioides strains using the 10-mer primer OPA2. Lanes 1-16, F. verticillioides strain 97L, 113B, 113F, 119Fa, 162A, 164G, 104Ga, 97J, 97K, 103BR, 103F, 103G, 103H, 118F, 119B and 119BR, respectively. The molecular mass standard (lane $\mathrm{M}$ ) is a $100 \mathrm{pb}$ ladder (Invitrogen Life Technologies, USA).

The dendrogram generated by 10 RAPD amplification patterns showed the genetic relationships among $16 F$. verticillioides strains (Fig. 2). The analysis based on RAPD markers revealed a clear trend of strains from the feed samples to cluster into three main groups: A, B and C (Fig. 2). Except for the strain 162A, which was the most dissimilar among all the strains 
analyzed, other 15 strains were divided into three distinct groups according to their banding patterns. Group A was composed by strains 97L, 97K, $113 \mathrm{~B}, 97 \mathrm{~J}, 113 \mathrm{~F}, 119 \mathrm{Fa}$ and $164 \mathrm{G}$, with around $75 \%$ of similarity; group B included the strains 104Ga, 103BR and 103G, also with approximately $75 \%$; and group $\mathrm{C}$ with the strains $103 \mathrm{~F}, 103 \mathrm{H}$, $118 \mathrm{~F}, 119 \mathrm{~B}$ and 119BR, and showing around 70\% of similarity. In clone/genotype identification, the resolution power is decided by the number of polymorphic loci used and the allele frequency. According to Wang et al. (1997), most of the clone genotypes in field populations of conifer canker pathogen Gremmeniella abietina could be identified with only a $10^{-10}-10^{-5}$ probability of error when 32 RAPD loci were used. In the current study, the 60 RAPD polymorphic loci were sufficient to discriminate all the strains, including the strains isolated from the same feed sample, e.g., strains $97 \mathrm{~J}, 97 \mathrm{~L}$ and $97 \mathrm{~K}$ from sample 97 (Fig. 2). This was not surprising, because even in the same plant many unrelated isolates could be found, suggesting multiple infections by independent spores (Wang et al., 1997). The infection of one corn plant with distinct biotypes of Fusarium genera has been a common event (Kedera et al., 1994).

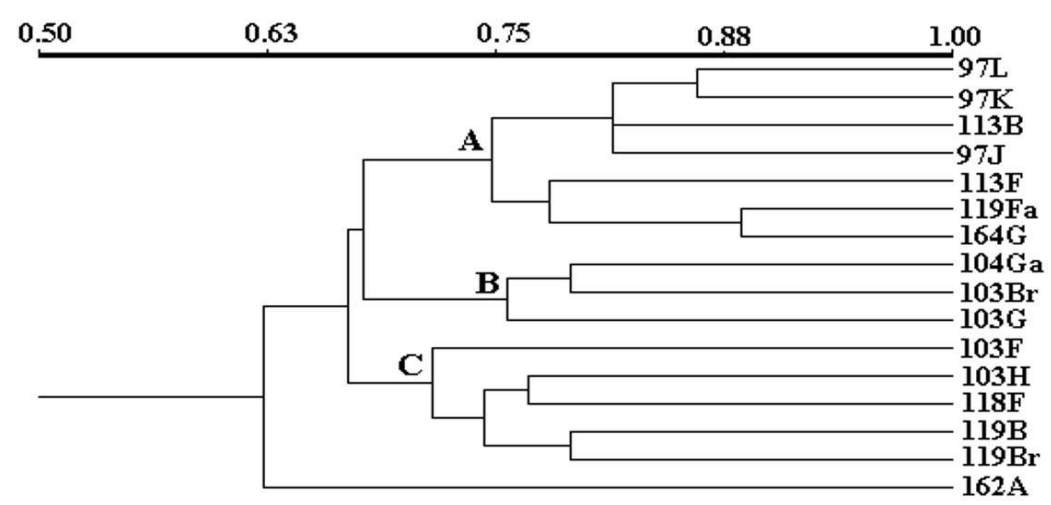

Figure 2 - UPGMA dendrogram based on the Jaccard similarity index (JS), illustrating the genetic relationships among $16 \mathrm{~F}$. verticillioides strains. Scale value of 1 indicates $100 \%$ of genetic similarity.

In fact, MacDonald and Chapman (1997) observed very distinctive $F$. verticillioides RAPD patterns between the strains isolated from the same kernel, indicating infection by more than one isolate. In the present study, the strains $164 \mathrm{G}$ and $162 \mathrm{~A}$, which were isolated from the same source, also showed very different RAPD profiles suggesting that they probably belonged to different colonies. Mitter et al. (2001) investigating $15 F$. verticillioides strains for their ability to produce gibberellins (GA) and their genetic relationship by RAPD, reported nearly identical RAPD patterns for high producers $(n=3)$, whereas the low and moderate producers showed a high degree of genetic diversity. Similarly, Jiménez et al. (2000), using RAPD markers in the analysis of twentynine Fusarium sp. strains (twenty-four belonging to Gibberella fujikuroi complex) isolated from banana and corn, detected a relationship between $\mathrm{FB}_{1} / \mathrm{FB}_{2}$ production and genetic variation showed by different Fusarium species investigated. Also, one of the six primers tested (OPA2) by these authors allowed to detect differences between low (not detected to $45.2 \mu \mathrm{g} / \mathrm{g}$ ) and high $\mathrm{FB}_{1}$ producing strains $(81.5$ to $4150 \mu \mathrm{g} / \mathrm{g})$. In disagreement with these findings, the analysis of $16 F$. verticillioides strains showed no clear association between RAPD makers and fumonisin production (Fig. 2, Table 3). Although three (103F, 119B and 119BR) out of four high fumonisin producing-strains clustered within group $\mathrm{C}$, suggesting a trend of high fumonisin producers clustering together, this trend found no support in a more careful analysis of the dendrogram (Fig. 2). Observing the group A, it was possible to notice that $97 \mathrm{~K}$ strain, which was classified as a high fumonisin producer (Tables 2 and 3), appeared included in this group together with low (164G, $113 \mathrm{G}$ and 113F) and moderate (97J and $119 \mathrm{Fa}$ ) producers. Except for $119 \mathrm{Fa}$ strain, all these four low and moderate fumonisinproducing strains produced mycotoxin levels statistically lower than the $97 \mathrm{~K}$ strain. These results were in agreement with Tran-Dinh et al. 
(1999), who compared the genetic relationship between the toxigenic and non-toxigenic strains of Aspergillus flavus and A. parasiticus by RAPD, and detected no association between RAPD genotypes and potency of toxin production.

Overall, the results obtained by RAPD marker analysis suggested that the $16 \mathrm{~F}$. verticillioides strains clustered mainly according to their corn feed source and locality of origin (Table 1 and Fig. 2). Pamphile and Azevedo (2002) used RAPD markers to assess the genetic diversity of $F$. verticillioides from different locations and detected clear associations between RAPD makers and populations sites.

Although RAPD markers were capable of discriminating different $F$. verticillioides strains, the results obtained in this study indicated that these markers were not suitable for distinguishing high and low fumonisin-producing strains. Thus, future approaches searching for new molecular markers able to discriminate between high and low fumonisin-producing strains would be a useful tool for corn quality monitoring.

\section{ACKNOWLEDGEMENTS}

The authors thank the $\mathrm{CNPq}$ for grant and fellowship to Brazilian researchers, the Araucária Foundation, Paraná Fund/SETI: CNPq/MAPA, PPSUS/Brazilian Ministry of Health, FINEP, CAPES (Co-ordination for Formation of High Level Professionals) and Japan International Cooperation Agency (JICA) for financial support. The $\mathrm{CNPq} / \mathrm{Pq}$ Scholarship is greatly appreciated by E.Y.S. Ono, M.H.P. Fungaro and E.Y. Hirooka.

\section{RESUMO}

Neste estudo, 16 cepas de $F$. verticillioides isoladas de amostras de ração de milho foram caracterizadas com base na produção de fumonisinas (FB) e em marcadores de polimorfismos de DNA amplificado ao acaso (RAPD). Todas as cepas produziram $\mathrm{FB}_{1}$ e $\mathrm{FB}_{2}$, com níveis variando, respectivamente, de 2,41 a $3996,36 \mu \mathrm{g} / \mathrm{g}$ e 1,18 a $1209,91 \mu \mathrm{g} / \mathrm{g}$. De acordo com a produção de fumonisinas totais $\left(\mathrm{FB}_{1}+\mathrm{FB}_{2}\right)$ e a distribuição por análise de quartis, do total de 16 cepas de $F$. verticillioides, quatro foram identificadas como baixas produtoras de fumonisinas $(3,59$ a $1289,84 \mu \mathrm{g} / \mathrm{g})$, oito como intermediárias (>1289,84 a $3772,44 \mu \mathrm{g} / \mathrm{g}$ ) e quatro como altas produtoras de fumonisinas $(>3772,44$ $\mu \mathrm{g} / \mathrm{g})$. Os 10 primers utilizados amplificaram 105 locos, $60(57,14 \%)$ dos quais foram polimórficos. As análises de RAPD mostraram padrões muito similares entre as cepas baixas, médias e altas produtoras de fumonisinas. Embora os marcadores RAPD tenham se mostrado capazes de discriminar as diferentes cepas de $F$. verticillioides, não foi detectada nenhuma associação entre estes marcadores e a produção de fumonisinas.

\section{REFERENCES}

Acuña, A.; Lozano, M.C.; García, M.C. and Diaz, G.J. (2005), Prevalence of Fusarium species of the Liseola section on selected Colombian animal feedstuffs and their ability to produce fumonisins. Mycopathologia, 160, 63-66.

Almeida, A.P.; Corrêa, B.; Mallozzi, M.; Sawazaki, E. and Soares, L.M.V. (2000), Mycoflora and aflatoxin/fumonisin production by fungal isolates from freshly harvested corn hybrids. Brazilian Journal of Microbiology, 31, 321- 326.

Andrews, S. and Pitt, J.I. (1986), Selective medium for Fusarium species and dermatiaceous hyphomycetes from cereals. Applied and Environmental Microbiology, 51, 1235-1238.

Carter, J.P.; Rezanoor, H.N.; Holden, D.; Desjardins, A.E.; Plattner, R.D. and Nicholson, P. (2002), Variation in pathogenicity associated with the genetic diversity of Fusarium graminearum. European Journal of Plant Pathology, 108, 573-583.

Cramer, R.A.; Byrne, P.F.; Brick, M.A.; Panella, L. and Wickliffe, E; Schwartz, H.F. (2003), Characterization of Fusarium oxysporum Isolates from common bean and sugar beet using pathogenicity assays and random-amplified polymorphic DNA markers. Journal of Phytopathology, 151, 352-360.

Edwards, S.G.; O'callaghan, J. and Dobson, A.D.W. (2002), PCR-based detection and quantification of mycotoxigenic fungi. Mycological Research, 106, 1005-25.

Fisher, N.L.; Burgess, L.W.; Toussoun, T.A. and Nelson, P.E. (1982), Carnation leaves as a substrate and for preserving cultures of Fusarium species. Phytopathology, 72, 151-153.

Gelderblom, W.C.A.; Jaskiewicz, K.; Marasas, W.F.O.; Thiel, P.G.; Horak, R.M.; Vleggaar R.; Kriek, N.P.J. (1988), Fumonisins - Novel mycotoxins with cancerpromoting activity produced by Fusarium moniliforme. Applied and Environmental Microbiology, 54, 1806 - 1811.

Hinojo, M.J.; Llorens, A.; Mateo, R.; Patiño, B.; González-Jaén, M. and Jiménez, M. (2004), Utility of the polymerase chain reaction-restriction fragment 
length polymorphisms of the intergenic spacer region of the rDNA for characterizing Gibberella fujikuroi isolates. Systematic and Applied Microbiology, 27, 681-688.

Jeffries, C.J.; Boyd, A.E.W. and Paterson, L.J. (1984), Evaluation of selective media for the isolation of Fusarium solani var. coeruleum and Fusariumsulphureum from soil and potato-tuber tissue. Annals of Applied Biology, 105, 471-481.

Jiménez, M.; Rodríguez, S.; Mateo, J.J.; Gil, J.V. and Mateo, R. (2000), Characterization of Gibberella fujikuroi complex isolates by fumonisin $\mathrm{B}_{1}$ and $\mathrm{B}_{2}$ analysis and by RAPD and restriction analysis of PCR-amplified internal transcribed spacers of ribosomal DNA. Systematic and Applied Microbiology, 23, 546-555.

Kedera, C.J.; Leslie, J.F. and Claflin, L.E. (1994), Genetic diversity of Fusarium section Liseola (Gibberella fujikuroi) in individual maize plants. Phytopathology, 84, 603-607.

Kini, K.R.; Leth, V. and Mathur, S.B. (2002), Genetic variation in Fusarium moniliforme isolated from seeds of different host species from Burkina Faso based on random amplified polymorphic DNA analysis. Journal of Phytopathology, 150, 209-212.

MacDonald, M.V. and Chapman, R. (1997), The incidence of Fusarium moniliforme on maize from Central America, Africa and Asia during 1992-1995. Plant Pathology, 46, 112-125.

Marasas, W.F.O.; Nelson, P.E. and Toussoun, T.A. (1984), Toxigenic Fusarium species: identity and mycotoxicology. Pennsylvania State University Press, Pennsylvania.

Miedaner, T.; Schilling, A.G. and Geiger, H.H. (2001), Molecular genetic diversity and variation for aggressiveness in populations of Fusarium graminearum and Fusarium culmorum sampled from wheat fields in different countries. Journal of Phytopathology, 149, 641-648.

Mitter, N.; Srivastava, A.C.; Ahamad, R.S.; Sarbhoy, A.K. and Agarwal, D.K. (2001), Characterization of gibberellin producing strains of Fusarium moniliforme based on DNA polymorphism. Mycopathologia, 153, 187-193.

Nash, S.M. and Snyder, W.C. (1962), Quantitative estimations by plate counts of propagules of the bean root rot Fusarium in field soils. Phytopathology, 52, 567-572.

Nelson, A.J.; Elias, K.S.; Arévalo, E.G.; Darlington, L.C. and Bailey B.A. (1997), Genetic Characterization by RAPD analysis of isolates of Fusarium oxysporum f. sp. erythroxyli associated with an emerging epidemic in Peru. Phytopathology, 87, 1220-1225.

Nelson, P.E.; Tousson, T.A. and Marasas, W.F.O. (1983), Fusarium species - An illustrated manual for identification. Pennsylvania State University Press, Pennsylvania.
Nicholson, P.; Chandler, E.; Draeger, R.C.; Gosman, N.E.; Simpson, D.R.; Thomsett, M. and Wilson, A.H. (2003), Molecular tools to study epidemiology and toxicology of Fusarium head blight of cereals. European Journal of Plant Pathology, 109, 691-703.

Pamphile, J.A. and Azevedo, J.L. (2002), Molecular characterization of endophytic strains of Fusarium verticillioides (=Fusarium moniliforme) from maize (Zea mays L.). World Journal of Microbiology and Biotechnology, 18, 391-396.

Raeder, U. and Broda, P. (1985), Rapid preparation of DNA from filamentous fungi. Letters in Applied Microbiology, 1, 16-20.

Rheeder, J.P.; Marasas, W.F.O. and Vismer, H.F. (2002), Production of fumonisin analogs by Fusarium species. Applied and Environmental Microbiology, 68, 2101-2105.

Rohlf, F.J. (2000), NTSYS-pc: numerical taxonomy and multivariate analysis system. NY: Exeter Software, Applied Biostatistics.

Shephard, G.S.; Sydenham, E.W.; Thiel, P.G. and Gelderblom, W.C.A. (1990), Quantitative determination of fumonisins $B_{1}$ and $B_{2}$ by highperformance liquid chromatography with fluorescence detection. Journal of Liquid Chromatography, 13, 2077-2087.

Sneath, P.H.A. and Sokal, R.R. (1973), Numerical taxonomy: the principles and practice of numerical classification. Freeman, San Francisco.

Sydenham, E.W.; Marasas, W.F.O.; Shephard, G.S.; Thiel, P.G. and Hirooka E.Y. (1992), Fumonisin concentrations in Brazilian feeds associated with field outbreaks of animal mycotoxicosis. Journal of Agricultural and Food Chemistry, 40, 994-997.

Tran-Dinh, N.; Pitt, J.I. and Carter, D.A. (1999), Molecular genotype analysis of natural toxigenic and nontoxigenic isolates of Aspergillus flavus and $A$. parasiticus. Mycological Research, 103, 1485-1490.

Ueno, Y.; Aoyama, S.; Sugiura, Y.; Wang, D.S.; Lee, U.S.; Hirooka, E.Y.; Hara, S.; Karki, T.; Chen, G. and $\mathrm{Yu}$, S.Z. (1993), A limited survey of fumonisins in corn and corn-based products in Asian countries. Mycotoxin Research, 9, 27-34.

Ueno, Y. (2000), Risk of multi-exposure to natural toxins. Mycotoxins, 50, 13-22.

Wang, X.R.; Ennos, R.A.; Szmidt, A.E. and Hansson, P. (1997), Genetic variability in the canker pathogen fungus, Gremmeniella abietina 2. Fine scale investigation of the population genetic structure. Canadian Journal of Botany, 75, 1460-1469.

Williams, J.G.K.; Kubelik, A.R.; Livak, K.J.; Rafalski, J.A. and Tingery, A.V. (1990), DNA polymorphisms amplified by arbitrary primers are useful as genetic markers. Nucleic Acids Research, 18, 6531-6535.

Received: June 25, 2008; Revised: November 10, 2008; Accepted: December 08, 2009. 